\title{
Miasto - region - gospodarka w badaniach prof. Ludwika Straszewicza
}

O pozycji naukowej i roli w rozwoju nauk geograficznych prof. Ludwika Straszewicza świadczy przede wszystkim jego bogaty dorobek naukowy. Obejmuje on ponad 250 opublikowanych prac (w tej liczbie 12 książek, liczne artykuły, notatki i recenzje oraz trzy atlasy), z czego ponad 50 ukazało się w wydawnictwach zagranicznych, we Francji, Czechosłowacji, Belgii, Włoszech, Hiszpanii, Niemczech, Bułgarii, USA, Japonii i na Węgrzech.

Działalność naukowa L. Straszewicza rozwijała się w kilku głównych nurtach, były to:

- geografia osadnictwa - geografia miast, zwłaszcza miast wielkich i pełniących funkcje stołeczne;

- geografia regionalna - w zakresie zagadnień społeczno-ekonomicznych (zwłaszcza region opolski i łódzki, a także europejskie kraje socjalistycznym i kraje romańskie);

- geografia gospodarcza - geografia przemysłu, przede wszystkim włókienniczego.

Te trzy wzmiankowane kierunki badawcze były obecne na wszystkich etapach działalności naukowej Profesora. Ponadto w pewnych okresach L. Straszewicz poświęcił wiele uwagi:

- funkcjom i roli geografii jako nauki stosowanej (druga połowa lat 60. i początek lat 70. XX w.); XX w.)

- badaniom przestrzennym emigracji polskiej we Francji (lata 80.

Rozległość zainteresowań L. Straszewicza sprawiała, że podejmował on również szereg innych, pobocznych i mniej ważkich w kontekście głównych nurtów realizowanych badań, tematów. Przykładem mogą tu być teksty poświęcone hodowli w XVIII w., zagadnieniom dydaktycznym, miejscowościom o nazwie Warszawa czy handlowi zagranicznemu Francji (Straszewicz 1956b: 161-176; Straszewicz 1962e: 72-77; Straszewicz 1963: 114-124; Straszewicz 1972: 97-100; Straszewicz 1974b: 263-267). 


\section{Miasto}

Osadnictwo to jeden z głównych nurtów badań uprawianych przez L. Straszewicza od początku jego kariery akademickiej w Uniwersytecie Łódzkim. Początkowo studia te koncentrowały się na problematyce ośrodków lokalnych i miały charakter dociekań empirycznych, silnie związanych $\mathrm{z}$ pracą $\mathrm{w}$ terenie i ukierunkowanych na praktykę. Ten profil badawczy, realizowany w końcu lat 50 . i w latach 60 ., był w dużym stopniu uwarunkowany brakiem doświadczenia i wcześniejszych tradycji w łódzkim ośrodku geografii społeczno-ekonomicznej lub słabo rozwiniętymi kontaktami z innymi akademickimi ośrodkami geograficznymi.

Pierwsze studia nad problematyką ośrodków lokalnych były realizowane przez L. Straszewicza w początkach lat 50., w okresie jego pobytu we Wrocławiu i dotyczyły Brzegu oraz Opola. W końcu tej dekady, już w Łodzi, Profesor kontynuował badania nad osadnictwem na Śląsku Opolskim - początkowo były to wiejskie jednostki osadnicze (Dobrzeń Wielki, Chróścice i in.), ale wkrótce badania objęły także miasta tego regionu. Prowadzone z inicjatywy i pod kierunkiem L. Straszewicza kompleksowe badania terenowe $\mathrm{i}$ inwentaryzacje urbanistyczne w kilkunastu miastach Opolszczyzny (m.in. Nysie, Głubczycach, Prudniku, Kluczborku, Gorzo-

12 wie Śląskim i Praszce) były w dużym stopniu ukierunkowane na potrzeby opracowania planów zagospodarowania przestrzennego. Cykl badań poświęconych problematyce ośrodków lokalnych na Opolszczyźnie zamyka opracowanie opublikowane w 1970 r. i przygotowane we współautorstwie, poświęcone Strzelcom Opolskim (Straszewicz 1964b: 113-126). W kolejnych latach z inicjatywy Profesora badania ośrodków lokalnych były kontynuowane $\mathrm{w}$ regionie łódzkim.

Szczególnie interesujące były studia Profesora dotyczące genezy, rozwoju i struktury przestrzennej wielkich miast i aglomeracji miejskich.

Na początku lat 60. L. Straszewicz podjął pierwsze badania, których podmiotem było wielkie europejskie miasto pełniące funkcje stołeczne, a ich efekt stanowiło przygotowanie monograficznego opracowania poświęconego aglomeracji Paryża, miasta szczególnie bliskiego Profesorowi ze względu na jego zainteresowanie krajami romańskimi i wcześniejsze kontakty z Francją jej kulturą i językiem. W 1963 r. w „Przeglądzie Geograficznym" (wiodącym czasopiśmie geograficznym tamtego okresu) opublikowany został artykuł Aglomeracja Paryża (Straszewicz 1963a: 591-614), który zapoczątkował serię opracowań Profesora poświęconych aglomeracjom innych wielkich stolic Europy: Londynu (Straszewicz 1965a: 3-28), Berlina (Straszewicz 1966: 77-105), Moskwy (Straszewicz 1969a: 179-210) i Rzymu (Straszewicz 1969c: 623-650). Ze wszystkich tych tekstów przebijała dogłębna znajomość analizowanej problematyki i solidne rozeznanie 
autora w specyfice każdego z badanych miast. Każde z opracowań odwoływało się do bogatej dokumentacji faktograficznej, co było możliwe dzięki wykorzystaniu materiałów źródłowych pozyskiwanych przez Profesora w czasie pobytów studyjnych $\mathrm{w}$ tych miastach. Zebrane $\mathrm{w}$ jednym tomie, po wprowadzeniu koniecznych zmian i uzupełnień, artykuły te, po blisko dziesięciu latach od przygotowania pierwszego z nich poświęconego stolicy Francji, ukazały się w formie książki zatytułowanej Wielkie stolice Europy (Straszewicz 1972e, wyd. II 1974d). Jak to zostało zaznaczone we wstępie, autor starał się odnaleźć cechy, które tak zdecydowanie różnią te wielkie metropolie, odszukać wątki ich wspólnoty cywilizacyjnej i poznać tajemnice ich odrębności. Poszczególne części książki cechuje podobna metoda opracowania, polegająca na historycznym przedstawieniu problematyki nowoczesnych wielkich metropolii. Do problematyki wielkich stolic Europy L. Straszewicz powrócił jeszcze na przełomie lat 70. i 80., publikując w "Przeglądzie Geograficznym” artykuły poświęcone kolejnym miastom stołecznym: Lizbonie (Straszewicz 1980a: 743-759) i Madrytowi (Straszewicz 1981: 295-321), a także przemianom funkcjonalnym innej wielkiej metropolii regionalnej Europy Zachodniej - Lyonu (Straszewicz 1987b: 131-163). W kontekście badań wielkich stolic Europy warto wspomnieć opracowania poświęcone Warszawie (m.in. Straszewicz 1974c: 51-62; Straszewicz 1983), pośród których jest jedno o drugorzędnym znaczeniu, świadczące jednak o rozległości zainteresowań Profesora i jego dociekliwości badawczej. Przedmiotem rozważań są w nim miejscowości o nazwie Warszawa (Straszewicz 1972c: 97-100).

Szeroko zakrojone studia nad wielkimi miastami i aglomeracjami miejskimi miały charakter wieloaspektowy i obejmowały zagadnienia genezy, uwarunkowań rozwoju i struktury przestrzennej obszarów zurbanizowanych. Problematykę wielkich miast przedstawiał Profesor zawsze w ujęciu genetycznym i dynamicznym, zarażał czytelników swoim zainteresowaniem ciągłością dziejów badanych miast, wskazywał wydarzenia progowe w ich rozwoju, wiążąc je ze zmianami funkcji. Szczególnie fascynowała go funkcja stołeczna, której istoty próbował dociec. Dużo uwagi poświęcał ewolucji układu przestrzennego, a także ekspansji miasta i procesom tworzenia się aglomeracji. Były to więc ujęcia bardzo wszechstronne (Koter 1997: 18).

Kilka opracowań Profesor poświęcił kluczowym z punktu widzenia wielkomiejskości strefom centralnym miast, szczególnie uwypuklając ich miejsce w strukturze funkcjonalnej przestrzeni miejskiej i specyfikę zagospodarowania (Straszewicz 1977: 1-4; Straszewicz 1982a: 31-43; Straszewicz 1985a: 155-169).

Ważną pozycją w dorobku Profesora, prezentującą syntetyczne ujęcie problematyki miejskiej i odwołującą się do szerokiej wiedzy autora, 
nie tylko geograficznej, lecz także historycznej i humanistycznej, był jeden z rozdziałów opublikowanego w 1978 r. przez Instituto Geografico de Agostini we Włoszech dzieła zatytułowanego L'Europa (Straszewicz 1978: 170-203). W tym monumentalnym opracowaniu zbiorowym - przygotowanym we współpracy z międzynarodowym zespołem wybitnych geografów włoskich, francuskich i brytyjskich - Profesor przygotował część poświęconą zagadnieniu urbanizacji Europy (L'urbanesimo).

Ważnym obiektem badań nad miastami była Łódź, której L. Straszewicz poświęcił wiele uwagi, dowodząc ważnych tez, pozwalających lepiej zrozumieć procesy rozwojowe zachodzące w tym mieście. Zwracał uwagę na unikalne cechy rozwoju i specyfikę Łodzi oraz aglomeracji łódzkiej (Straszewicz 1975b: 15-17; Straszewicz 1976: 9-21; Straszewicz 1979c: 17-23), a także Łódzkiego Okręgu Przemysłowego, którego trzon stanowiła Łódź. Przedmiotem rozważań była struktura funkcjonalna miasta, a zwłaszcza jego funkcja gospodarcza (Straszewicz 1962c: 103-117), migracje ludności (Straszewicz 1956a: 775-794; Straszewicz 1963c: 361-375) oraz specyfika Łodzi jako ośrodka regionalnego. Badania obejmowały także otoczenie miasta - strefę podmiejska, oddziaływanie na bliższe i dalsze zaplecze oraz powiązania funkcjonalne (m.in. Straszewicz 1991: 3-17).

Jeden $\mathrm{z}$ bardziej istotnych wniosków akcentowanych w publikacjach 14 Profesora dotyczył specyfiki Łodzi jako ośrodka miejskiego, który w przeciwieństwie do innych polskich miast nie miał własnej, w pełni ukształtowanej, strefy podmiejskiej.

Specyfika Łodzi - historia tego miasta i jego współczesność (lata 50.-80. XX w.) - sprawiła, że L. Straszewicz, podejmując tematykę łódzka, stał się także uznanym badaczem z zakresu problematyki rozwoju i struktury przestrzennej miast przemysłowych. Profesor podkreślał znaczenie przemysłu włókienniczego w rozwoju Łodzi i konsekwencje jej przemysłowego charakteru dla organizacji i zagospodarowania przestrzeni miejskiej. Zainteresowanie Łodzią i miejscem tego miasta w sieci osadniczej kraju zaowocowało stworzeniem koncepcji badań nad „drugimi miastami", które w systemie osadniczym krajów europejskich plasowały się za miastami stołecznymi. Skutkiem tego ujęcia było dążenie Profesora do rozwijania kontaktów z "odpowiednikami” Łodzi w innych krajach, zwłaszcza Lyonem i Barceloną.

Szeroko zakrojone badania Łodzi zainicjonowane przez L. Straszewicza (i kontynuowane przez jego uczniów) sprawiły, że dziś miasto to dysponuje jedną z najbogatszych bibliografii z zakresu problematyki społeczno-ekonomicznej i rozwoju przestrzennego.

Znaczące z merytorycznego punktu widzenia są prace L. Straszewicza poświęcone strefie podmiejskiej Łodzi. Pierwsze z nich zostały opublikowane już w pierwszej połowie lat 50. Przyjmując założenie, że jeśli 
"aglomeracja ma wyraźny punkt centralny w postaci wielkiego miasta, wielokrotnie przewyższający wielkościa zaludnienia i zabudowy inne osiedla wchodzace w jej skład, wówczas można traktować taka forme osiedleńcza jako miasto wraz ze strefa podmiejska", Profesor sformułował i udowodnił tezę, że „strefa podmiejska Łodzi nie jest należycie wykształcona [i źle zorganizowana] $i$ że region podłódzki w bardzo małym stopniu odpowiada pojęciu strefy podmiejskiej wielkiego miasta", m.in. ze względu na brak właściwie rozwiniętych miast-satelitów, kontrast między ogromną gęstością zaludnienia w samym mieście i na otaczających terenach wiejskich, ograniczone funkcje wypoczynkowe i dojazdy do pracy w Łodzi z zaplecza (Straszewicz 1954: 182-197; Straszewicz 1955: 29-30). Z kolei w artykule poświęconym rolnictwu w strefie podmiejskiej Łodzi L. Straszewicz formułuje warunki niezbędnej dla rozwoju, intensywnej produkcji rolnej na potrzeby miasta, kładąc nacisk na konieczność wykorzystania ścieków miejskich i zabezpieczenia zaopatrzenia w wodę rolnictwa, a zwłaszcza szczególnie odczuwającego jej niedobór ogrodnictwa (Straszewicz 1957b: 87-110).

Istotnym osiągnięciem Profesora - którego prace stały się inspiracją do podjęcia szerzej zakrojonych badań nad problematyką stref podmiejskich - była próba sformułowania teoretycznych podstaw i uporządkowania sfery pojęciowej, aby możliwe było prowadzenie pogłębionych badań nad zasięgiem, strukturą i funkcjami stref podmiejskich polskich miast (Straszewicz 1980c: 1-17; Straszewicz 1985e: 7-16). Okazją do podjęcia szeroko zakrojonej ogólnopolskiej dyskusji naukowej nad zdefiniowaniem i metodami badań stref podmiejskich stała się kolejna, zorganizowana w 1970 r., ",ódzka konferencja styczniowa".

Obok publikacji podejmujących problematykę poszczególnych ośrodków miejskich, L. Straszewicz kilka tekstów poświęcił również analizie sieci osadniczej w Polsce (Straszewicz 1967a: 115-130; Straszewicz 1975: 923-932), wskazując m.in., że „wyjaśnienie roli przemysłu w rozwoju sieci osiedleńczej [...] może być przeprowadzone tylko poprzez studia porównawcze, obejmujace wiele krajów o rozmaitym stopniu rozwoju ekonomicznego" (Straszewicz 1970c: 3-19). Badania z zakresu geografii osadnictwa, zapoczątkowane przez L. Straszewicza, były także prowadzone przez uczniów Profesora i są do dziś rozwijane, stanowiąc jeden z podstawowych nurtów badawczych, realizowanych w łódzkim ośrodku geografii społeczno-ekonomicznej. Można tu wspomnieć m.in. badania nad morfologią i morfogenezą miast (M. Koter, M. Kulesza), miejskim użytkowaniem ziemi (S. Liszewski), procesami demograficznymi i strukturą ludności miast (J. Dzieciuchowicz), budownictwem mieszkaniowym i warunkami zamieszkania w miastach (J. Dzieciuchowicz, T. Marszał), strukturą funkcjonalną miast (A. Suliborski), procesami urbanizacyjnymi w strefach podmiejskich (J. Jakóbczyk-Gryszkiewicz), zróżnicowaniem przestrzennym warunków 
życia w mieście (S. Liszewski), uwarunkowaniami rozwoju i zagospodarowaniem przestrzennym małych miast (T. Marszał), funkcjami obszarów metropolitalnych (S. Liszewski, T. Marszał, A. Wolaniuk).

\section{Region}

Zainteresowanie problematyką regionalną znalazło swoje odzwierciedlenie już w pierwszej poważniejszej pracy naukowej L. Straszewicza, którą był jego doktorat (ukończony w 1949 r.), przygotowany pod kierunkiem prof. Józefa Wąsowicza i poświęcony charakterystyce równiny wrocławskiej w kontekście znaczenia tego regionu dla polskiej gospodarki narodowej (Straszewicz 1949). Najwcześniejsze prace (przygotowane we współautorstwie), które można zaliczyć do nurtu regionalnego, zostały opublikowane w 1948 r. - były to opracowania odnoszące się do ośmiu dolnośląskich powiatów i zrealizowane dla potrzeb praktyki planowania przestrzennego.

Pierwszą książkową monografią regionalną autorstwa L. Straszewicza, która ukazała się w 1956 r., była pozycja poświęcona geografii gospodarczej województwa opolskiego, zawierająca nie tylko charaktery-

16 stykę poszczególnych działów gospodarki, lecz także opis środowiska przyrodniczego (Straszewicz 1956c). O znaczeniu tego opracowania i jego użyteczności najlepiej świadczy fakt, że w pierwszej połowie lat 60. ukazały się kolejne dwie, znacznie rozszerzone, poprawione i uzupełnione, wersje tej pracy, przy czym ostatnie wydanie przygotowane było na zlecenie National Science Foundation w Waszyngtonie w języku angielskim (Straszewicz 1962f).

Bardzo podobny do monografii Śląska Opolskiego zakres tematyczny i formę redakcyjną miał zarys geograficzno-ekonomiczny województwa łódzkiego (Straszewicz 1967c). Przedmiotem szczególnego zainteresowania Profesora była analiza uwarunkowań i perspektyw rozwoju regionu łódzkiego, w którym ważną rolę regionotwórczą pełniło przetwórstwo włókiennicze (Straszewicz 1960a: 71-79; Straszewicz 1961a: 295-314; Straszewicz 1969b; Straszewicz 1972d: 1-15). Analizując sytuację gospodarczą regionu łódzkiego początku lat 70., L. Straszewicz wskazywał, że „województwo łódzkie powoli, ale systematycznie zmienia charakter rolniczo-przemysłowy na przemysłowo-rolniczy, jednak perspektywa jego rozwoju opiera się zarówno na przemyśle, jak i nowoczesnym, intensywnym rolnictwie" (Straszewicz 1972d: 14).

Swoistym dopełnieniem monografii książkowych było opracowanie atlasów, województwa opolskiego (Straszewicz 1962a) i województwa łódzkiego (Straszewicz 1965b), które były pierwszymi tego typu opracowaniami w skali kraju i w tamtym czasie stanowiły wzór regionalnego 
studium ekonomiczno-geograficznego z zastosowaniem metod kartograficznych. Opublikowane w latach 60. pozycje książkowe, wraz z dwoma atlasami, stanowiły merytoryczną całość w obrębie problematyki regionalnej odnoszącej się do wybranych fragmentów polskiej przestrzeni, które stanowiły przedmiot szczególnych zainteresowań Profesora w tamtym okresie. Do problematyki regionalnej, ujmowanej w takim formacie merytorycznym i zakresie przestrzennym w kolejnych latach, na dalszych etapach pracy naukowej Profesor już nie powracał - wyjątkiem było opracowanie w pierwszej połowie lat 70. atlasu województwa bydgoskiego (Straszewicz 1973a).

Już w latach 60. w twórczości naukowej L. Straszewicza miejsce badań regionalnych w skali wewnątrzkrajowej stopniowo zajmowały opracowania monograficzne poświęcone wybranym krajom. Ważną inspirację do podjęcia takich prac stanowiło pragnienie przybliżenia polskiemu czytelnikowi problematyki geograficznej, a także upowszechnienie znajomości historii, kultury, zagadnień przyrodniczych i społeczno-ekonomicznych krajów europejskich. Profesor podjął prace nad przygotowaniem kompleksowych monografii geograficznych krajów Europy Środkowo-Wschodniej. Pierwsza pozycja książkowa poświęcona „,krajom demokracji ludowej" została opracowana we współpracy z S. Zajchowską i J. Kremky-Saloni - ukazała się w dwóch tomach w latach 1966-1968 (Kremky-Saloni, Straszewicz, Zajchowska 1966; Kremky-Saloni, Straszewicz, Zajchowska 1968) i miała drugie wydanie (1970). Ostatecznym efektem badań regionalnych tej części Europy, realizowanych przez Profesora, była publikacja jednotomowego, niezwykle obszernego (liczącego ponad 800 stron) i trzykrotnie wznawianego dzieła - kompendium wiedzy na temat geografii ekonomicznej europejskich krajów socjalistycznych początku lat 70. XX w. (Straszewicz 1974a, wyd. 2. uzupełnione 1979b, wyd. zmienione w jęz. jap. 1982c). Książka ta, autorstwa L. Straszewicza, wprawdzie nawiązywała do wcześniej wydanego dwutomowego opracowania zbiorowego, ale zawierała znacznie rozszerzony zakres merytoryczny, a ponad to - niezależnie od części poświęconych NRD, Czechosłowacji, Węgrom, Rumunii, Bułgarii, Jugosławii i Albanii - część poświęconą geografii regionalnej Polski. Każda z części zawierała rozdziały odnoszące się do terytorium (granic i podziału administracyjnego), środowiska przyrodniczego, ludności, surowców i górnictwa, przemysłu, rolnictwa, lasów i gospodarki leśnej, transportu i komunikacji, osadnictwa oraz handlu zagranicznego. Pomimo tego schematycznego układu poszczególne części tej książki różnią się między sobą z uwagi na indywidualność opisywanych krajów, której autor nie chciał pomijać, podkreślając specyficzne cechy i odrębności każdego z nich. Pozycja ta w zamierzeniu autora miała spełniać rolę podręcznika akademickiego. 
W latach 70. badania regionalne L. Straszewicza wkraczają w kolejny etap - Profesor koncentruje swoje wysiłki na przygotowaniu geograficznych monografii kolejnych krajów romańskich. Serię książek poświęconych tej tematyce otwiera monografia Francji (Straszewicz 1972b). Kilka lat później ukazuje się monografia Włoch (Straszewicz 1977), a następnie Hiszpanii (Straszewicz 1982b). Pracę nad monografią Portugalii przerywa śmierć Profesora. Wszystkie te opracowania, odzwierciedlające zainteresowanie L. Straszewicza kulturą romańską dają kompleksowy obraz opisywanych krajów - autor z równym znawstwem przedstawia historię, środowisko przyrodnicze, kulturę i uwarunkowania rozwoju społeczno-gospodarczego. Ta wnikliwa analiza regionalna była możliwa tylko dzięki znakomitemu rozeznaniu i wiedzy nabytej podczas wielomiesięcznych pobytów Profesora w każdym z tych krajów.

Wszystkie prace Profesora z zakresu problematyki regionalnej, niezależnie od tego, czy dotyczyły Polski, czy innych krajów, były zawsze rezultatem bardzo starannych studiów odwołujących się do dostępnej literatury, z wykorzystaniem materiałów źródłowych, pozyskanych w trakcie licznych wyjazdów.

Problematyka regionalna, której Profesor L. Straszewicz poświęcił tak wiele uwagi, znalazła swoje odbicie także w pracach jego współpracowników i uczniów. Badania o charakterze regionalnym dotyczyły m.in. województwa łódzkiego i Polski Środkowej (S. Liszewski, S. Pączka), koncepcji podziału terytorialnego kraju (M. Koter), a także zasięgu regionu łódzkiego (A. Suliborski).

\section{Gospodarka}

Problematyka geografii ekonomicznej w dorobku naukowym L. Straszewicza zaznacza się w całkiem odmienny sposób niż geografia miast czy geografia regionalna. Teksty o gospodarce są bodaj najliczniejsze w bibliografii Profesora (tylko zagadnieniom geografii przemysłu poświecił blisko 40 artykułów, nie licząc tekstów dotyczących innych działów gospodarki narodowej i nawiązujących do tej tematyki, a zamieszczonych w opracowaniach regionalnych), jednak brak pozycji o zwartym, całościowym charakterze - wyłącznie temu zagadnieniu nie została poświęcona żadna pozycja książkowa. Ponadto zainteresowania L. Straszewicza problematyką gospodarczą - choć wyraźnie skoncentrowane wokół zagadnień przemysłu, a zwłaszcza przemysłu włókienniczego - są o wiele bardziej heterogeniczne. W wielu opracowaniach zostały silnie powiązane $\mathrm{z}$ analizą zagadnień osadniczych i, co zrozumiałe, są obecne we wszystkich opracowaniach regionalnych. Większość monografii regionalnych Profesora, choć poruszane są w nich zagadnienia przyrodnicze, historyczne i społeczne, ma wyraźne nachylenie ekonomiczne. 
Pierwszym tekstem o istotnych walorach poznawczych, dotyczącym problematyki przemysłu, był opublikowany w drugiej połowie lat 50 . artykuł poświęcony Łodzi, w którym autor - nawiązując do szeroko dyskutowanej w literaturze geograficznej teorii kompleksów przemysłowych - dowiódł, że nie tylko przemysł ciężki, lecz także przetwórstwo włókiennicze może stanowić istotny element bazy ekonomicznej miasta i regionu, decydujący o osiągnięciu statusu kompleksu przemysłowego, który „charakteryzuje różnorodność istniejacych gałęzi przemystu, wynikajaca z rozwoju przemystów towarzyszacych produkcji podstawowej" (Straszewicz 1957a: 741-777). Kontynuacją dla badań, wpisujących się w nurt szeroko wówczas podejmowanych na gruncie nauk geograficznych zagadnień kompleksów przemysłowych, była analiza porównawcza łódzkiego okręgu przemysłowego i okręgu przemysłowego Kamienicy Saskiej w kontekście całościowo ujmowanych problemów lokalizacji działalności gospodarczej (Straszewicz 1960c: 64). W tekście tym została przedstawiona specyfika układu przestrzennego Łódzkiego Okręgu Przemysłowego i odrębność, jaką wykazywał w porównaniu w okręgiem Kamienicy Saskiej, przy czym niektóre $\mathrm{z}$ tych specyficznych cech autor uznał za zjawiska negatywne. L. Straszewicz zwrócił uwagę na względnie niski stopień zainwestowania $\mathrm{w}$ łódzkim przemyśle silną koncentracją potencjału produkcyjnego w centrum okręgu łódzkiego i nierównomierne uprzemysłowienie regionu łódzkiego, co różniło zasadniczo ten obszar od regionu Kamienicy Saskiej, gdzie rozbieżności w tym zakresie między poszczególnymi powiatami i miastami były znacznie mniejsze.

Problematyka Łódzkiego Okręgu Przemysłowego zajmowała Profesora szczególnie i była przedmiotem wieloaspektowych analiz, odnoszących się nie tylko do elementów konstytuujących kompleks przemysłowy i warunkujących jego przeobrażenia (Straszewicz 1979d: 149-163), lecz także do uwarunkowań rozwoju i unikatowego charakteru miast przemysłowych regionu, dojazdów i rozmieszczenia miejsc pracy (Straszewicz 1962d; Straszewicz 1963c: 361-375; Straszewicz 1964a: 163-173) oraz miastotwórczej i regionotwórczej roli przemysłu włókienniczego (Straszewicz 1958a: 25-48; Straszewicz 1959a: 69-91; Straszewicz 1960a: 71-79; Straszewicz 1960: 60-63; Straszewicz 1961a: 295-314).

Z oczywistych względów geograficzno-ekonomiczne badania Łodzi i otaczającego miasto regionu były silnie powiązane $z$ zagadnieniami przetwórstwa włókienniczego, a podejmowanie problematyki tej gałęzi przemysłu L. Straszewicz uważał za obowiązek wynikający z miejsca, w którym przyszło mu funkcjonować i roli, jaką włókiennictwo odgrywało w rozwoju Łodzi i regionu. Jednak to zainteresowanie nie ograniczało się tylko do łódzkiego przemysłu tekstylnego - przedmiotem rozważań były także inne polskie i zagraniczne ośrodki i regiony produkcji włókienni- 
czej. Przykładem mogą być artykuły analizujące wybrane branże surowcowe i wybrane czynniki lokalizacji tej gałęzi w Polsce (Straszewicz 1959b: 251-283; Straszewicz 1984: 104-108; Straszewicz 1985b: 107-116). L. Straszewicz był inicjatorem wszechstronnych badań struktur przestrzennych włókiennictwa w NRD, Czechosłowacji i na Węgrzech, opublikował też opracowania na temat włókiennictwa bułgarskiego (Straszewicz 1961: 663-678), francuskiego (Straszewicz 1962g: 309-331), japońskiego (Straszewicz 1970a: 113-122), odnoszące się do wymiaru globalnego (Straszewicz 1958b: 551-553; Straszewicz 1984b: 137-138).

Dzięki wysiłkom L. Straszewicza - który skupił wokół siebie międzynarodowe grono badaczy zainteresowanych tą problematyką - łódzki ośrodek akademicki stał się silnym centrum badań geografii włókiennictwa, nie tylko w skali krajowej, lecz także międzynarodowej. W pełni uprawnione jest stwierdzenie, że inicjując tak szeroko zakrojone badania przestrzennych aspektów włókiennictwa i wytyczając w latach 70.-80. kierunki podejmowanych prac na tym polu, Profesor w pewnym sensie nobilitował tę - nieco pozostająca poza głównym nurtem zainteresowań decydentów gospodarczych i badań naukowych - gałąź przemysłu. Jego zasługą było zwrócenie uwagi na miastotwórcze znaczenie oraz rolę przetwórstwa tekstylnego w gospodarce wielu państw i regionów, w których gałąź ta pełniła funkcję "lokomotywy" w procesie przyspieszonego rozwoju gospodarczego.

Profesor publikował również opracowania geograficzno-przemysłowe, prezentujące bardziej ogólne spojrzenie na rolę, lokalizację i strukturę przestrzenną tego działu gospodarki narodowej (Straszewicz 1962: 2-7; Straszewicz 1963b: 299-306; Straszewicz 1967a: 115-130; Straszewicz 1970c: 3-19; Straszewicz 1972a: 191-201; Straszewicz 1979f: 11-19; Straszewicz 1980b: 29-33), a także poświęcone innym wybranym gałęziom przemysłu, produkcji samochodów (Straszewicz 1965c: 301-303; Straszewicz 1979b: 77-88), energetyce (Straszewicz 1973b: 436-437) i hutnictwu (Straszewicz 1977b: 60-61; Straszewicz 1979e: 241-242).

Istotne miejsce $\mathrm{w}$ dorobku L. Straszewicza zajmowały rozważania na temat geografii przemysłu jako subdyscypliny naukowej, jej miejsca i roli w systemie nauk geograficznych oraz znaczenia jako przedmiotu nauczania akademickiego (Straszewicz 1986: 25-33; Straszewicz 1987a: 8-13). Ważną konstatacją płynącą z tych tekstów jest stwierdzenie, że geografia przemysłu jest niezależną i oddzielną subdyscypliną geografii, spośród wszystkich działów geografii ekonomicznej najbardziej zbliżoną do nauk ekonomicznych.

Warto wreszcie wspomnieć, że w początkach kariery akademickiej w Uniwersytecie Łódzkim L. Straszewicz opublikował kilka drobniejszych prac poświęconych problematyce rolniczej (Straszewicz 1956b: 161-176; 
Straszewicz 1957b: 87-110), co jest o tyle charakterystyczne, że w późniejszych latach, pomimo rozległości zainteresowań badawczych Profesora, zagadnienia geografii rolnictwa były całkiem nieobecne $\mathrm{w}$ bibliografii łódzkiego ośrodka geografii społeczno-ekonomicznej, pojawiły się dopiero w XXI w. (zob. prace M. Wójcika).

Badania geograficzno-gospodarcze były kontynuowane przez uczniów Profesora - można tu wspomnieć m.in. studia nad rozwojem, lokalizacją i strukturą przestrzenną przemysłu włókienniczo-odzieżowego w Polsce (S. Pączka) i na świecie (T. Marszał), rozwojem i strukturą przestrzenną Bełchatowskiego Okręgu Przemysłowego (S. Liszewski, S. Pączka, A. Niżnik), restrukturyzacją przemysłu Łodzi i aglomeracji łódzkiej (S. Pączka, T. Marszał, E. Marczyńska-Witczak), rolą przemysłu w przestrzeni lokalnej (T. Marszał) - jednak po jego śmierci zasadniczej zmianie uległa ich struktura. Wraz z przekształceniami zachodzącymi w Polsce i w regionie łódzkim w okresie transformacji gospodarczej, stopniowo zainteresowanie geografią przemysłu zeszło na drugi plan, całkowicie zarzucone zostały badania problematyki włókienniczej, natomiast zagadnienia gospodarcze są podejmowane $\mathrm{w}$ szerszym ujęciu i wpisują się w kontekst badań z zakresu gospodarki przestrzennej.

\section{Funkcje i rola geografii jako nauki stosowanej}

W wielu pracach L. Straszewicz podkreślał praktyczne znaczenie prowadzonych rozważań, stwierdzając, że „właściwa ocena [zjawisk], dokonana przez geografów ma nie tylko znaczenie poznawcze - służy ona praktycznym celom planowania regionalnego $i$ stanowi podstawe dla wykonywanych urbanistycznych planów zagospodarowania przestrzennego" (Straszewicz 1960a: 79).

Wyrazem zainteresowania geografią stosowaną była redakcja dwóch tomów „Przeglądu Zagranicznej Literatury Geograficznej”, opublikowanych w latach 1967 i 1970. Tomy te były wynikiem aktywnej działalności L. Straszewicza w Komisji Geografii Stosowanej Międzynarodowej Unii Geograficznej. W drugim z nich znalazły się teksty poświęcone przygotowaniu zawodowemu geografów pod kątem praktyki. L. Straszewicz wyrażał przekonanie, że geografia nie może pozostawać jedynie dyscypliną uniwersytecką i przedmiotem nauczania w szkołach, a program geograficznych badań podstawowych i teoretycznych powinien być realizowany równolegle z pracami praktycznymi, przydatnymi dla administracji terytorialnej i gospodarki narodowej (Straszewicz 1970b: 7). Uważał, że pożądane jest, aby kariera absolwentów geografii rozkładała się na rozmaite zawody, wśród których nauczyciel jest jednym z wielu, i aby poza szkolnictwem znajdowali oni także zatrudnienie w praktyce. Wyrażał opinię, 
że ważne jest zainteresowanie geograficznych instytutów naukowych i katedr uniwersyteckich zastosowaniem praktycznym prac badawczych oraz udziałem pracowników naukowych w życiu politycznym i gospodarczym kraju, podejmowanie funkcji ekspertów przy opracowywaniu planów regionalnych i urbanistycznych oraz realizacja prac badawczych na zlecenie praktyki (Straszewicz 1967b: 1-2). Tam, gdzie geografia pozostaje jedynie dyscypliną uniwersytecką i przedmiotem nauczania w szkołach, nie cieszy się większym prestiżem i jej społeczna rola jest niewielka (Straszewicz 1970b: 7). Podobne opinie na temat roli geografii jako wiedzy praktycznej i przydatności zawodowej geografów wyrażał L. Straszewicz w artykułach opublikowanych w drugiej połowie lat 60. na łamach „Życia Szkoły Wyższej" (Straszewicz 1965e: 74-77; Straszewicz 1969d: 121-127).

Poglądy L. Straszewicza w sprawie geografii stosowanej prowadziły m.in. do konstatacji, że geografowie - uprawiając swoją dyscyplinę zgodnie z zasadami i prawami, którymi się ona odznacza - powinni być otwarci na współpracę z innymi dyscyplinami naukowymi (Straszewicz 1986: 31).

\section{Badania przestrzenne emigracji polskiej we Francji}

Wieloletnie kontakty L. Straszewicza z geografią francuską i wielokrotne pobyty w ośrodkach akademickich tego kraju zaowocowały w latach 80 . kolejną inicjatywą badawczą - wieloletnim programem badań nad Polonią francuską. Studia te koncentrowały się wokół zagadnień struktury przestrzennej mniejszości polskiej we Francji i jej roli w organizacji przestrzeni, także w wymiarze lokalnym i regionalnym. Efektem zakrojonych na szeroką skalę prac był opublikowany już po śmierci Profesora Atlas Polonii francuskiej (Marszał 2001), do którego L. Straszewicz przygotował siedem plansz (wraz z komentarzem tekstowym), prezentujących rozmieszczenie, strukturę i segregację przestrzenną ludności pochodzenia polskiego we Francji w połowie lat 70. XX w. (Straszewicz 2001a: 24-25; Straszewicz 2001e: 26-27; Straszewicz 2001g: 28-29; Straszewicz 2001d: 30-31; Straszewicz 2001b: 32-33; Straszewicz 2001c: 34-35; Straszewicz 2001f: 36-37).

W dorobku publikacyjnym Profesora znajdują się także - oprócz ogólnego omówienia idei badań polonijnych w łódzkim ośrodku geograficznym (Straszewicz 1985c: 3-6) - teksty poświęcone polskiej emigracji w aglomeracji Lyonu (Straszewicz 1985d: 53-68; Straszewicz 1988: 67-80). W mieście tym Profesor spędził kilka lat, wykładając na tamtejszych uniwersytetach i zbierając materiały do kolejnych publikacji. W opracowaniach tych L. Straszewicz, odwołując się do historii polskiej emigracji we Francji, omawia genezę Polonii w regionie Rhône-Alpes i na podstawie różnych dostępnych źródeł podejmuje próbę oszacowania liczby i rozmieszczenia Polaków w aglomeracji Lyonu (Courly). 
To zainteresowanie problemem mniejszości narodowych i Polonii, czyli Polaków, którzy znaleźli się poza granicami kraju, znajdowało swój wyraz już w najwcześniejszych, opublikowanych tuż po II wojnie światowej, tekstach L. Straszewicza, nawiązujących do losów ludności serbołużyckiej (Straszewicz 1945b; Straszewicz 1945a), a także w czasie zagranicznych wizyt studialnych.

\section{Uwagi końcowe}

Podział na kierunki badawcze, jak każda próba identyfikacji i klasyfikacji działalności naukowej, jest z natury rzeczy uproszczony i umowny; również niezwykle trudny w przypadku L. Straszewicza - nie był on geografem, którego jednoznacznie można przypisać do określonej subdyscypliny geograficzno-ekonomicznej. W różnych okresach działalności naukowej podejmował bardzo zróżnicowaną tematykę badawczą wśród jego publikacji znajdują się pozycje z zakresu m.in. geografii osadnictwa, geografii ludności, geografii przemysłu, rolnictwa i transportu, dydaktyki geografii, a także - i może przede wszystkim - z zakresu geografii regionalnej, przy czym w opracowaniach monograficznych, oprócz zagadnień społeczno-ekonomicznych, Profesor nie unikał rozważań odnoszących się do środowiska przyrodniczego opisywanych regionów. Można powiedzieć, że L. Straszewicz - z uwagi na wszechstronne wykształcenie i rozległe zainteresowania - był „geografem renesansu”. Pewnym zwornikiem znaczącej części badań Profesora, w ujęciu przestrzenno-tematycznym, była Łódź i otaczający miasto region, Śląsk Opolski oraz kraje romańskie, a w ujęciu "branżowym" - miasto, przemysł i region.

Z publikacji naukowych L. Straszewicza przebija umiejętność szerszego, interdyscyplinarnego spojrzenia na badania geograficzne. Jego zainteresowania, gruntowna wiedza - nie tylko geograficzna, lecz także historyczna i ekonomiczna - oraz zrozumienie, że "czyste” badania geograficzne, ograniczające się do opisu zjawisk fizycznych (także tych mających wymiar ekonomiczny) i ich rozmieszczenia należą do przeszłości, zaowocowały otwarciem na współpracę z innymi dyscyplinami wiedzy (ekonomią, socjologia, urbanistyką) oraz dążeniem do powiązania prowadzonych prac badawczych z praktyką (Marszał 2009: 41-42). $\mathrm{W}$ swoich pracach nie stronił od analiz nawiązujących do dorobku ekonomii oraz odniesień do historycznych i społecznych aspektów badań przestrzennych.

Ważną rolę w życiu naukowym Profesora odegrały lata spędzone we Wrocławiu, co wyrażało się silnym zainteresowaniem problematyką Śląska. Badania nad tym regionem i na jego rzecz ujmował w kategoriach 
patriotycznego obowiązku. Szczególnie wiele uwagi poświęcał problematyce Śląska Opolskiego, który w pierwszym okresie powojennym był pozbawiony instytucji akademickich.

Na kierunki prowadzonych badań istotny wpływ miały doświadczenia zawodowe Profesora w sferze planowania, m.in. kierowanie zespołem opracowującym 16-tomowe studia i przygotowującym Wstępna koncepcje planu regionalnego Łódzkiego Okręgu Przemysłowego. W dalszej, już akademickiej, karierze Profesora przejawiało się to silnym zainteresowaniem problematyką łódzką i przemysłem włókienniczym konstytuującym to miasto.

Doświadczenie wyniesione z praktyki miało niewątpliwy wpływ na postrzeganie znaczenia badań naukowych, które oprócz podstawowych wartości teoretycznych powinny kłaść nie mniejszy nacisk na walor użyteczności. Profesor był zaprzeczeniem reprezentowanej przez szereg środowisk naukowych postawy nadmiernego i oderwanego od życia teoretyzowania, a za jedno z kluczowych kryteriów celowości podejmowania badań uważał możliwość ich praktycznej aplikacji - można więc powiedzieć, że był przedstawicielem geografii stosowanej.

L. Straszewicz, tak bardzo dbający o aplikacyjny wymiar prowadzonych prac, uważał, że profil badań naukowych realizowanych $\mathrm{w}$ konkretnym ośrodku naukowym powinien odpowiadać potrzebom miasta i regionu, a tematy opracowań naukowych winny uwzględniać specyfikę otaczającej badacza rzeczywistości. Konsekwencją takiego podejścia był duży udział w dorobku naukowym Profesora prac poświęconych Łodzi i Polsce środkowej.

Trudno też nie zauważyć, że badania prowadzone przez L. Straszewicza i tematyka jego publikacji w pewnym stopniu nawiązują do kierunków badań w geografii światowej trzeciego ćwierćwiecza XX w., a zwłaszcza do nurtu reprezentowanego przez geografię francuską - Profesor przez szereg lat, wykładając na uniwersytetach francuskich i odbywając liczne wizyty w zagranicznych uczelniach, czerpał z tych międzynarodowych kontaktów inspiracje do własnych badań.

Specyfikę prac prowadzonych przez L. Straszewicza wyznaczał nie tylko ich zakres merytoryczny, lecz także dobór określnych metod badawczych. W wielu opracowaniach Profesor szeroko wykorzystywał wyniki badań terenowych, takich jak pomiary ruchu, inwentaryzacja, ankietowanie czy zdjęcie użytkowania ziemi. Badania terenowe pozwalały na zdobycie cennych materiałów źródłowych, ale przede wszystkim dawały podstawę do krytycznego i trzeźwego spojrzenia na wyniki prowadzonych prac analitycznych. Profesor często odwoływał się do potrzeby realistycznego i praktycznego postrzegania rze- 
czywistości, której zrozumienie i opisanie - a także interpretacja zachodzących procesów - nie mogła polegać wyłącznie na stosowaniu choćby najbardziej wyrafinowanych metod prowadzących do wyników nie oddających realiów analizowanych zjawisk przestrzennych. Szereg prac L. Straszewicza ma charakter studiów porównawczych (komparatystycznych), które pozwalały na uzyskanie pełniejszego obrazu analizowanych zjawisk.

Profesor chętnie podejmował nowe, w znaczeniu przedmiotowym, tematy, natomiast - prezentując bardzo pragmatyczne stanowisko - nie wykazywał większego zainteresowania teorią i filozofią nauki. Traktował geografię raczej jako intersującą i przydatną wiedzę, która zgodnie z klasycznym wzorcem badawczym ma niewiele do zaoferowania w zakresie studiów teoretycznych i metodologicznych - a nie „wielką naukę" (Suliborski 2009: 35).

Analiza dorobku L. Straszewicza pozwala zaliczyć go do grona uczonych reprezentujących $\mathrm{w}$ geografii orientację klasyczno-realistyczną, co wynikało z jego krytycznego stosunku do zachodzących w latach 60.-70. XX w. zmian w sposobie uprawiania tej dyscypliny (tzw. „rewolucji ilościowej w geografii”), a także $z$ reprezentowanego przez Profesora realizmu poznawczego i przywiązania do tradycji. Stąd jego zaangażowanie w problematykę regionalna, w której upatrywał sedno badań geograficznych. Profesorowi odpowiadała przede wszystkim metoda słownego opisu, opartego na poznaniu z autopsji obiektu badania oraz wykorzystaniu dostępnej wiedzy historycznej i materiałów źródłowych, pozyskanych ze statystyki i w trakcie badań terenowych. To realistyczne stanowisko badawcze przekładało się na podejmowanie działań, mających na celu powiązanie badań naukowych z praktyką społeczno-gospodarczą (Suliborski 2009: 31-33).

Publikacje Profesora - niezależnie od wartości merytorycznych i od tego, czy pisał o środowisku przyrodniczym, zagadnieniach demograficznych, osadniczych czy problemach ekonomicznych - są pisane bardzo dobrym językiem.

Dziś, pomimo upływu trzech dziesięcioleci od śmierci L. Straszewicza, jego dorobek naukowy stanowi ważny element dziedzictwa łódzkiego ośrodka geografii społeczno-ekonomicznej. I choć zasadniczo zmieniły się zewnętrzne uwarunkowania, a wraz z nimi pojawiły się nowe wyzwania i nowe problemy badawcze, podejmowane przez kolejne pokolenia łódzkich geografów, to kierunki prac naukowych realizowanych przez Profesora, kontynuowane i pogłębiane przez jego uczniów, nadal stanowią o pozycji oraz specyfice łódzkiego ośrodka akademickiego na geograficznej mapie Polski. 


\section{Literatura}

Koter M. (1997), Profesor Ludwik Straszewicz. W siedemdziesięciolecie urodzin i trzydziestolecie objęcia kierownictwa Katedry Geografii Ekonomicznej Uniwersytetu Łódzkiego, „Sylwetki Łódzkich Uczonych", z. 4, ŁTN, Łódź, s. 13-22.

Kremky-Saloni J., Straszewicz L., Zajchowska S. (1966), Geografia gospodarcza europejskich krajów demokracji ludowej, cz. I, PWE, Warszawa.

Kremky-Saloni J., Straszewicz L., Zajchowska S. (1968), Geografia gospodarcza europejskich krajów demokracji ludowej, cz. II, PWE, Warszawa.

Liszewski S., Pączka S., Straszewicz L. (1970), Strzelce Opolskie jako ośrodek cią̇enia. Związki miasta z zapleczem poprzez ruchy ludności, [w:] W. Dziewulski, J. Kroszel (red.), Ziemia Strzelecka. Szkice monograficzne, Instytut Śląski, Opole, s. 247-302.

Marszał T., red. (2001), Atlas of Polish emigration in France / Atlas Polonii francuskiej, Stowarzyszenie Wspólnota Polska, Uniwersytet Łódzki, Łódź.

Marszał T. (2009), Ludwik Straszewicz - mistrz z perspektywy ucznia (krótkie wspomnienie), [w:] Łódzka szkoła geografii społeczno-ekonomicznej. Dyskusja wokót sylwetki mistrza - profesora Ludwika Straszewicza, ŁTN, Łódź, s. 38-42.

Straszewicz L. (1945a), Los Łużyc lė̇y nam na sercu, „Pionier Dolnośląski”, 16-17.XII.

Straszewicz L. (1945b), Stowiański kraj, o którym zapomniano, „Pionier Dolnośląski”, 7.XII.

Straszewicz L. (1949), Równina Wrocławska i jej znaczenie dla Polskiego Gospodarstwa Narodowego, mpis pracy doktorskiej, Uniwersytet Wrocławski (promotor: Józef Wąsowicz), Wrocław.

Straszewicz L. (1954), Strefa podmiejska Łodzi, „Przegląd Geograficzny”, t. 26, z. 4, s. 182-197.

Straszewicz L. (1955), Strefa podmiejska jako problem urbanistyczny, „Miasto”, R. 6, nr 12 (62), s. $29-30$.

Straszewicz L. (1956a), Rozmieszczenie miejsc pracy i zamieszkania w Łódzkim Okręgu Przemysłowym, „Przegląd Geograficzny”, t. 28, z. 4, s. 775-794.

Straszewicz L. (1956b), Stan i rozmieszczenie hodowli na Ślasku w drugiej połowie XVIII wieku, „Czasopismo Geograficzne", t. 27, z. 2, s. 161-176.

Straszewicz L. (1956c), Województwo opolskie. Zarys geografii gospodarczej, PWN, Warszawa.

Straszewicz L. (1957a), Kompleks przemystowy Łodzi, "Przegląd Geograficzny”, t. 29, z. 4, s. 741-777.

Straszewicz L. (1957b), Problemy rolnicze strefy podmiejskiej Łodzi, „Przegląd Geograficzny”, t. 29 , z. 1, s. 87-110.

Straszewicz L. (1958a), Łódzki Okręg Przemysłowy w projekcie planu regionalnego, „Łódzkie Czasopismo Gospodarcze", nr 1, s. 25-48.

Straszewicz L. (1958b), Światowa konsumpcja włókien sztucznych, „Czasopismo Geograficzne", t. 29, z. 4, s. 551-553.

Straszewicz L. (1959a), The Eódź industrial district as a subject of investigations of economic geography, „Przegląd Geograficzny”, t. 29, Suplement, s. 69-91.

Straszewicz L. (1959b), Polski przemyst bawetniany, „Przegląd Geograficzny”, t. 31, z. 2, s. 251-283.

Straszewicz L. (1960a), Analiza podstaw rozwoju regionu geograficzno-gospodarczego na przykładzie badań Łódzkiego Okręgu Przemysłowego, „Łódzkie Czasopismo Gospodarcze”, nr 6, s. 71-79.

Straszewicz L. (1960b), Lokalisationsphänomene der Industrie im Textilindustriegebiet von Łódź, "Geographische Berichte“, H. 14, s. 60-63 [przygotowanie do druku K. Scherf].

Straszewicz L. (1960c), Studium porównawcze okręgu łódzkiego i okręgu Kamienicy Saskiej $w$ aspekcie kompleksowych problemów lokalizacji przemystu, „Łódzkie Czasopismo Gospodarcze", nr 5, s. 31-64. 
Miasto - region - gospodarka w badaniach prof. Ludwika Straszewicza

Straszewicz L. (1961a), Analyse des bases du développement des régions économiques tirée de l'example de la région industrielle de Łódż, [w:] Problems of economic region: papers of the Conference on Economic Regionalization in Kazimierz (Poland), May 29 -June 1, 1959, ed. Z. Dziewoński, Instytut Geografii i Zagospodarowania Przestrzennego PAN, ,Prace Geograficzne", nr 27, s. 295-314.

Straszewicz L. (1961b), Bułgarski przemyst włókienniczy, „Przegląd Geograficzny”, t. 33, z. 4, s. 663-678.

Straszewicz L. (1962a), Atlas gospodarczy województwa opolskiego, PPWK, Warszawa, 16 map + tekst $4 \mathrm{~s}$.

Straszewicz L. (1962b), Les changements dans de localisation des industries en Pologne, „Bulletin de l'Association de Géographes Français", vol. 303-304, s. 2-7.

Straszewicz L. (1962c), Łódź jako ośrodek gospodarczy, [w:] E. Rosset (red.), Łódź w latach 19451960, PWN, Łódź, s. 103-117.

Straszewicz L. (1962d), Migrations of the inhabitants of the industrial centers situated in the neighbourhood of Łódź, Second Anglo-Polish Geographical Seminar, England.

Straszewicz L. (1962e), Studia zaoczne geografii w Uniwersytecie Łódzkim, „Życie Szkoły Wyższej", R. 10, nr 10, s. 72-77.

Straszewicz L. (1962f), Ślask Opolski. Zarys geografii gospodarczej, Katowice.

Straszewicz L. (1962g), Włókiennictwo francuskie i jego rola w gospodarce kraju, „Przegląd Geograficzny", t. 34, z. 2, s. 309-331.

Straszewicz L. (1963a), Aglomeracja Paryża, „Przegląd Geograficzny”, t. 35, z. 4, s. 591-614.

Straszewicz L. (1963b), Problémes urbains et industriels en Pologne, „Revue de Géographie de l'Est", vol. 3, no. 3, s. 299-306.

Straszewicz L. (1963c), Wędrózoki ludności jako podstawa rozwoju miast przemysłowych na przykładzie aglomeracji łódzkiej, „Czasopismo Geograficzne”, t. 34, z. 4, s. 361-375.

Straszewicz L. (1963d), Wybrane zagadnienia dydaktyczne z zakresu kształcenia zaocznego na kierunku geografii, [w:] Uniwersyteckie studia dla pracujacych, Wyd. Uniwersytetu Wrocławskiego, Wrocław, s. 114-124.

Straszewicz L. (1964a), Migration movements in four industrial towns near Łódź 1956-1961, "Geographia Polonica", t. 3, s. 163-173.

Straszewicz L. (1964b), Zespót osiedleńczy Gorzów Śląski-Praszka na tle problemów zagospodarowania byłego pogranicza, "Materiały i Studia Opolskie”, t. 10, s. 113-126.

Straszewicz L. (1965a), Aglomeracja Londynu, „Przegląd Geograficzny”, t. 37, z. 1, s. 3-28.

Straszewicz L., red. (1965b), Atlas województwa łódzkiego, PPWK, Warszawa, 24 mapy + tekst $4 \mathrm{~s}$.

Straszewicz L. (1965c), Francuski przemyst samochodowy, „Czasopismo Geograficzne”, t. 36, z. 3, s. 301-303.

Straszewicz L. (1965d), Opole Silesia. Outline of Economic Geography, Warszawa.

Straszewicz L. (1965e), Przydatność zawodowa geografów, „Życie Szkoły Wyższej”, nr 1, s. $73-77$.

Straszewicz L. (1966), Aglomeracja Berlina, „Przegląd Geograficzny”, t. 38, z. 1, s. 77-105.

Straszewicz L. (1967a), L'industrie et le développement du réseau urbain, „Geographia Polonica", t. 12, s. $115-130$.

Straszewicz L. (1967b), Przedmowa, [w:] Geografia stosowana, cz. III, „Przegląd Zagranicznej Literatury Geograficznej", z. 4, s. 1-10.

Straszewicz L. (1967c), Województwo łódzkie. Zarys geograficzno-ekonomiczny, PWN, Warszawa.

Straszewicz L. (1969a), Aglomeracja Moskwy, „Przegląd Geograficzny”, t. 41, z. 2, s. 179-210.

Straszewicz L. (1969b), Podstawowe problemy regionu łódzkiego, [w:] Podstawowe problemy ekonomiczne regionu łódzkiego, Materiały na Sesję Naukowa, Łódź [maszynopis powielany]. 
Straszewicz L. (1969c), Rzym jako metropolia światowa, „Przegląd Geograficzny”, t. 41, z. 4, s. 623-650.

Straszewicz L. (1969d), W sprawie przydatności uniwersyteckiego wykształcenia geograficznego dla praktyki, „Życie Szkoły Wyższej”, nr 5, s. 121-127.

Straszewicz L. (1970a), Nowe tendencje lokalizacyjne w japońskim przemyśle bawetnianym, „Przegląd Geograficzny”, t. 52, z. 1, s. 113-122.

Straszewicz L. (1970b), Przedmowa, [w:] Geografia stosowana, cz. IV, „Przegląd Zagranicznej Literatury Geograficznej", z. 1, s. 3-8.

Straszewicz L. (1970c), Rola przemystu w rozwoju sieci miast w Polsce, "Zeszyty Naukowe UŁ”, Ser. II, Nauki Matematyczno-Przyrodnicze, z. 38: Geografia ekonomiczna, s. 3-19.

Straszewicz L. (1972a), Changes in distribution of Poland's industry after the Second World War, [w:] Studies in Applied Geography in Commemoration of Professor Syed Muzaffor Ali, Aligarh, s. 191-201.

Straszewicz L. (1972b), Francja, PWN, Warszawa.

Straszewicz L. (1972c), Miejscowości o nazwie Warszawa, "Zeszyty Naukowe UŁ”, Ser. II, Nauki Matematyczno-Przyrodnicze, z. 49: Geografia ekonomiczna, s. 97-100.

Straszewicz L. (1972d), Perspektywy rozwoju województwa łódzkiego, „Zeszyty Naukowe U乇”, Ser. II, Nauki Matematyczno-Przyrodnicze, z. 49: Geografia ekonomiczna, s. 1-15.

Straszewicz L. (1972e), Wielkie stolice Europy", wyd. I, PWN, Warszawa.

Straszewicz L. (1973a), Atlas województwa bydgoskiego, Wyd. Geologiczne, Warszawa, 32 mapy + tekst 5 s. [współpraca: Instytut Geografii UMK, Toruń].

Straszewicz L. (1973b), Elektrownia pływowa Rence po 5 latach działalności, „Czasopismo Geograficzne", t. 44, z. 3-4, s. 436-437.

Straszewicz L. (1974a), Geografia ekonomiczna europejskich krajów socjalistycznych, PWE, Warszawa.

Straszewicz L. (1974b), Handel zagraniczny Francji w 1971 r., "Czasopismo Geograficzne”, t. 45 , z. 2, s. $263-267$.

Straszewicz L. (1974c), Warszawa na tle stolic Europy, „Kronika Warszawy”, nr 2, s. 51-62.

Straszewicz L. (1974d), Wielkie stolice Europy, wyd. II, PWN, Warszawa.

Straszewicz L. (1975a), Changements du réseau urbain en Pologne (1950-1970), [w:] Scritti geografici in onore di Riccardo Riccardi, Societa Geografica Italiana, Roma, s. 923-932.

Straszewicz L. (1975b), Indywidualność Łodzi na tle aglomeracji miejskich, [w:] XIII Ogólnopolski Zjazd Polskiego Towarzystwa Geograficznego, Łódź, 28-30.VI.1975. Tezy i streszczenia referatów, Wyd. Uniwersytetu Łódzkiego, Łódź, s. 15-17.

Straszewicz L. (1976), Samobytnost' goroda Łodzi w ekonomik-geografičeskom aspekcie, [w:] Problemy geografii naselenia $i$ ispol'zovania territorii, Izd. Tbiliskogo Universiteta, Tbilisi, s. 9-21.

Straszewicz L. (1977a), Centra miejskie jako temat zainteresowań geografów, [w:] L. Straszewicz (red.), Niektóre problemy teoretyczne z geografii miast. Materiaty konferencyjne, Wyd. Uniwersytetu Łódzkiego, Łódź, s. 1-4.

Straszewicz L. (1977b), Rustawi - centrum gruzińskiej czarnej metalurgii, „Czasopismo Geograficzne", t. 48, z. 2, s. 60-61.

Straszewicz L. (1977c), Włochy, PWN, Warszawa.

Straszewicz L. (1978), L'urbanesimo, [w:] E. Turri (ed.), L'Europa, Instituto Geografico de Agostini, Novara, s. 170-203.

Straszewicz L. (1979a), Francuski przemyst samochodowy wobec tendencji koncentracji i rozproszenia, "Przegląd Geograficzny”, t. 40, z. 1, s. 77-88.

Straszewicz L. (1979b), Geografia ekonomiczna europejskich krajów socjalistycznych, wyd. II uzupełnione, PWE, Warszawa. 
Miasto - region - gospodarka w badaniach prof. Ludwika Straszewicza

Straszewicz L. (1979c), Indywidualność Łodzi na tle aglomeracji miejskich, „Acta Universitatis Lodziensis", Zeszyty Naukowe Uniwersytetu Łódzkiego, Ser. II, Nauki Matematyczno-Przyrodnicze, Folia Geographica, z. 21: Problematyka geograficzna regionu łódzkiego, s. $17-23$.

Straszewicz L. (1979d), Łódź. La mutacion de un complejo industrial, "Estudios Geográficos", vol. 40 , no. 155 , s. $149-163$.

Straszewicz L. (1979e), Sytuacja hutnictwa w wysoko rozwiniętych krajach kapitalistycznych, "Czasopismo Geograficzne", t. 50, z. 3, s. 241-242.

Straszewicz L. (1979f), Udziat przemystu w ksztattowaniu przestrzeni miejskiej, [w:] L. Straszewicz (red.), Rola przemystu w rozwoju miast i miasto jako baza działalności przemysłowej. Materiały konferencyjne, Wyd. Uniwersytetu Łódzkiego, Łódź 1979, s. 11-19.

Straszewicz L. (1980a), Lizbona, „Przegląd Geograficzny”, t. 52, z. 4, s. 743-759.

Straszewicz L. (1980b), Locational problems of industry in planned economy countries, University of Birmingham, s. 29-33.

Straszewicz L. (1980c), Strefa podmiejska. Pojęcia i definicje, [w:] Pojęcia i metody badań strefy podmiejskiej. Materiały XIII Łódzkiej Konferencji Naukowej, Wyd. Uniwersytetu Łódzkiego, Łódź, s. 1-17.

Straszewicz L. (1981), Aglomeracja Madrytu, „Przegląd Geograficzny”, t. 53, z. 2, s. 295-321.

Straszewicz L. (1982a), Centr goroda - termin, geografičeskaya problematika, issledovatel'skaja tematika, [w:] Problemy geografii naseleniya i prostranstvennoj organizacji, Izd. Tbiliskogo Universiteta, Tbilisi, s. 31-43.

Straszewicz L. (1982b), Hiszpania, PWN, Warszawa.

Straszewicz L. (1982c), Kraje socjalistyczne Europy [w jęz. japońskim, tłum. z jęz. francuskiego Take Tanioka], Sanseid Co., Tokyo.

Straszewicz L. (1983), Warsaw: Capital city in the national system, "Ekistics", Vol. 50, No. 299, s. $98-103$.

Straszewicz L (1984a), La rôle de la main - d'oeuvre textile dans l'organisation de l'espace en Pologne, "Hommes et Terres du Nord", no. 2, s. 104-108.

Straszewicz L. (1984b), Zmiany w przemyśle włókienniczym na świecie, "Acta Universitatis Lodziensis", Folia Geographica, z. 3, s. 137-138.

Straszewicz L. (1985a), Défense - biurowe śródmieście poza granicami Paryża, „Acta Universitatis Lodziensis", Folia Geographica, z. 4, s. 155-169.

Straszewicz L. (1985b), Les problemes fondamentaux des matières premières de l'industrie textile polonaise, "Treballes de la Societat Catalana de Geografia", vol. 3, s. 107-116.

Straszewicz L. (1985c), O badaniach przestrzennych Polonii Francuskiej, [w:] T. Marszał, B. Pasikowska, L. Straszewicz (red.), Problemy rozmieszczenia ludności pochodzenia polskiego we Francji. Les. Problèmes de la répartition géographique de la population d'origine polonaise en France. Materiały z konferencji naukowej, Łódź 1985, Wyd. Uniwersytetu Łódzkiego, Łódź, s. 3-6.

Straszewicz L. (1985d), Problemy określania wielkości i rozmieszczenia społeczności polskiej w regionie Lyonu, [w:] T. Marszał, B. Pasikowska, L. Straszewicz (red.), Problemy rozmieszczenia ludności pochodzenia polskiego we Francji. Les. Problèmes de la répartition géographique de la population d'origine polonaise en France. Materiaty z konferencji naukowej, Łódź 1985, Wyd. Uniwersytetu Łódzkiego, Łódź, s. 53-68.

Straszewicz L. (1985e), Strefa podmiejska. Pojęcia i definicje, [w:] Pojęcia i metody badań strefy podmiejskiej, „Acta Universitatis Lodziensis”, Folia Geographica, z. 5, s. 7-16.

Straszewicz L. (1986), Miejsce i rola geografii przemystu w systemie nauk i studiów geograficznych, "Acta Universitatis Lodziensis”, Folia Geographica, z. 7, s. 25-33. 
Straszewicz L. (1987a), Geografia przemystu jako nauka i dyscyplina nauczania, [w:] Geografia przemystu w akademickim kształceniu nauczycieli, „Materiały i Sprawozdania”, z. 14, Kraków, s. 8-13.

Straszewicz L. (1987b), Lyon - przemiany funkcjonalne wielkiej metropolii regionalnej Europy Zachodniej, „Acta Universitatis Lodziensis”, Folia Geographica, z. 8, s. 131-163.

Straszewicz L. (1988), Zbiorowość polska w aglomeracji Lyonu, „Przegląd Polonijny”, R. 14, z. 4 , s. 67-80.

Straszewicz L. (1991), Łódź w społeczno-gospodarczej przestrzeni Polski, „Acta Universitatis Lodziensis", Folia Geographica, z. 13, s. 3-17.

Straszewicz L. (2001a), Changes in the spatial distribiution of Polish population in France, 19541975 (in selected departments) / Zmiany w rozmieszczeniu ludności polskiej we Francji w latach 1954-1975, [w:] T. Marszał (red.), Atlas of Polish emigration in France / Atlas Polonii francuskiej, Łódź, s. 24-25.

Straszewicz L. (2001b), Proportion of naturalised Poles in the total Polish population in France in 1975 by departments / Udział Polaków naturalizowanych w ogólnej liczbie ludności polskiej we Francji w roku 1975 wedtug departamentów, [w:] T. Marszał (red.), Atlas of Polish emigration in France / Atlas Polonii francuskiej, Łódź, s. 32-33.

Straszewicz L. (2001c), Proportion of Poles (including naturalised persons)in the total foreign population in France in 1975, by departments / Udziat Polaków (wraz z naturalizowanymi) w ogólnej liczbie cudzoziemców we Francji w roku 1975 wedtug departamentów, [w:] T. Marszał (red.), Atlas of Polish emigration in France / Atlas Polonii francuskiej, Łódź, s. 34-35.

Straszewicz L. (2001d), Proportion of Poles (including naturalised persons) in the total population of France in 1975, by departments / Udział Polaków (wraz z naturalizowanymi) w ogólnej liczbie ludności we Francji w roku 1975 wedtug departamentów, [w:] T. Marszał (red.), Atlas of Polish emigration in France / Atlas Polonii francuskiej, Łódź, s. 30-31.

Straszewicz L. (2001e), Spatial distribution of the Polish population in France in 1975 (including naturalised persons) / Rozmieszczenie ludności polskiej we Francji w roku 1975 (wraz z osobami naturalizowanymi), [w:] T. Marszał (red.), Atlas of Polish emigration in France / Atlas Polonii francuskiej, Łódź, s. 26-27.

Straszewicz L. (2001f), Sex structure of the Polish population (including naturalised persons) in France in 1975, by departments / Struktura ptci ludności polskiej (wraz z osobami naturalizowanymi) we Francji w roku 1975 wedtug departamentów, [w:] T. Marszał (red.), Atlas of Polish emigration in France / Atlas Polonii francuskiej, Łódź, s. 36-37.

Straszewicz L. (2001g), Structure of the Polish population in France in 1975 by nationality status and place of residence / Struktura ludności polskiej we Francji w roku 1975 według narodowościowego statusu prawnego i miejsca zamieszkania, [w:] T. Marszał (red.), Atlas of Polish emigration in France / Atlas Polonii francuskiej, Łódź, s. 28-29.

Suliborski A. (2009), Profesor Ludwik Straszewicz - twórca łódzkiej szkoły geografii społeczno-ekonomicznej, [w:] Łódzka szkoła geografii społeczno-ekonomicznej. Dyskusja wokół sylwetki mistrza - profesora Ludwika Straszewicza, ŁTN, Łódź, s. 29-38.

Tadeusz Marszał, prof. dr hab., Katedra Zagospodarowania Środowiska i Polityki Przestrzennej, Wydział Nauk Geograficznych, Uniwersytet Łódzki 